TECHNICAL TRANSACTIONS 7/2019

CIVIL ENGINEERING

DOI: $10.4467 / 2353737$ XCT.19.074.10725

\author{
Alicja Kowalska-Koczwara (D) orcid.org/0000-0001-8088-7729 \\ akowalska@pk.edu.pl \\ Krzysztof Stypuła iD orcid.org/0000-0001-8679-526X \\ kstypula@pk.edu.pl \\ Institute of Structural Mechanics, Cracow University of Technology
}

\title{
New POLISH GUIDELINES REgARDING HUMAN EXPOSURE TO VIBRATIONS IN BUILDINGS
}

NOWE POLSKIE WYTYCZNE DOTYCZĄCE NARAŻENIA LUDZI NA WIBRACJE

W BUDYNKACH

\begin{abstract}
Following global trends, Polish regulations on human exposure to vibration in buildings were changed and new Polish guidelines were published in June 2017. In accordance with international trends, two methods of assessment have been added to the regulations: basic RMS method and ad-ditional VDV method. For more clarity of RMS method, the human vibration perceptivity ratio (HVPR) was introduced to new Polish regulations. In the appendix to the Polish standard, the vi-bration dose value (VDV) method is presented. The third important change in the new version of the Polish standard is measurement equipment that should be used for human perception evaluation. New regulations have precisely described what kind of equipment should be used for low-frequency recording and a new measurement disc for the human perception of vibration on floors has been introduced to the Polish standard.

Keywords: human exposure to vibration, standard regulations, RMS method, VDV, measurements
\end{abstract}

\section{Streszczenie}

Podążąączaświatowymi trendami, polskie przepisy dotyczące narażenia ludzi na wibracje wbudynkach zostaly zmienione, a nowe polskie wytyczne zostaly opublikowane w czerwcu 2017 r. Zgodnie z międzynarodowymi trendami w przepisach ujęto dwie metody ewaluacji: podstawową metodę RMS i dodatkową metodę VDV. Dla większej przejrzystości metody RMS do nowych polskich przepisów wprowadzono Wskaźnik Odczuwalności Drgań przez Ludzi (WODL). W zalączniku do polskiej normy przedstawiono metodę dawki drgań (VDV). Trzecią ważną zmianą w nowej wersji polskiej normy jest sprzęt pomiarowy, który należy wykorzystać w pomiarach oceny odczuwalności drgań człowieka. Nowe przepisy precyzyjnie opisaty, jakiego rodzaju sprzęt powinien być używany do rejestracji niskich częstotliwości, do polskiej normy wprowadzono także nowy dysk pomiarowy służący do pomiaru wpływu drgań na ludzi w budynkach.

Słowa kluczowe: narażenie ludzi na drgania, przepisy normowe, metoda RMS, VDV, pomiary 


\section{Introduction}

There are many sources of vibration in the vicinity of buildings in urban areas that can have an influence on building structure but can also be annoying for residents. In the diagnosis and design of the building, such influences should be taken into account. In urban areas, traffic vibrations from roadways [15], tramways [11], railways [13] are the basic excitation. In highrise buildings located in the urban areas of many countries, wind-induced vibrations could have a significant influence on the structures [10]. In the Silesian region of Poland, mining excitation also occurs [20]. Irrespective of the source of excitation, vibrations in buildings could be annoying for residents. International standards relating to the human response to building vibrations include limits on the levels of ground-born vibrations transmitted through subsoil to buildings. All of the reviewed national standards base the limits for acceptable vibration on indoor vibration levels. This means that vibration measurements must be performed inside the building in the room in which occupants are. Conducting in-situ measurements can be problematic due to the requirement to gain the consent of owners to access the property. Most national standards are stated in terms of either the average or the maximum passive vibration level; rarely are adjustments included to account for the number and duration of vibration events. One exception is British Standard [4], which states a criterion based on total vibration exposure. In the newest version of British Standard [3], the total time of exposure is also be taken into account. In the nineteen-eighties, when the most recognisable and widely used ISO $[6,7]$ standards were published, some new trends in the context of human exposure to vibration in buildings were investigated. The frequency range in which the evaluation of human exposure to vibration is mostly considered in national standards is in the range of 1 to $80 \mathrm{~Hz}$. In Japan, where many very tall pencil-like buildings with small transverse dimensions are often found, the evaluation of human exposure to vibrations starts at frequencies below $1 \mathrm{~Hz}$, [1]. Additionally, one ISO standard, [8], considers frequencies from 0.1 to $1 \mathrm{~Hz}$. National and international standards differ from each other in the weighting curves which are used to determine the threshold of human perception of vibration. Weighting functions were determined according to laboratory tests. In the provisions of ISO [6] and British [3] standards, there are small differences in weighting functions in the vertical direction $(\mathrm{z})$. They differ in frequencies below $5 \mathrm{~Hz}$ and in frequencies higher than $25 \mathrm{~Hz}$. For the most unpleasant frequencies for the human body $(5-25 \mathrm{~Hz})$, the weighting functions are the same in both standards. The most problematic is the ISO [7] standard in which the combined weighting function $(\mathrm{Wm})$ is applied when the position of the human body during the measurement is unknown. The differences between the three weighting functions present in the [6, 7 and 3$]$ standards are shown in Fig. 1.

In [12] authors took four weighting functions $(W b, W k, W g$, and $W m)$ into account in their $V D V$ analysis. The $W g$ function is the weighting curve for the horizontal directions. The $W b$ and $W k$ were found to be more applicable than $W g$ and $W m$ with regard to explaining the perception of floor vibration.

Duration of vibration is the main problem in standards because in most of them, the duration of vibration is not clearly described. Of course, in each of the considered standards, there is 


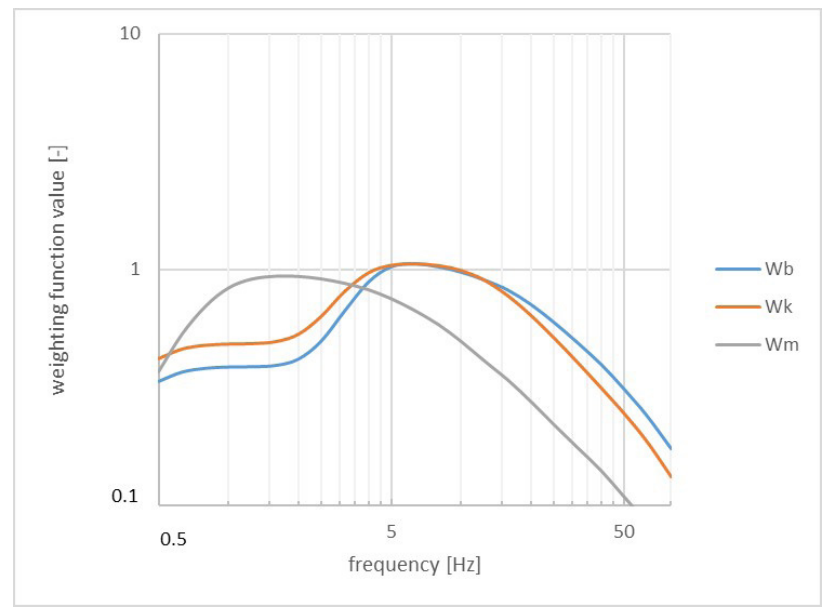

Fig. 1. Comparison between weighting functions

exposure time (daytime: 6.00-22.00, night: 22.00-6.00; with the exception of the British standard in which the day starts at 7.00 and ends at 23.00) but this is not equal to the duration of vibration. ISO [7] says of the duration of measurement that it "should be sufficient to ensure reasonable statistical precision". This definition is very wide and imprecise despite the duration of vibration having a significant influence on the result of signal analysis. In the German standard [5], measurement analysis is performed in 30-second cycles which are then averaged. Generally speaking, a minimum of 30 seconds of recorded signal should be considered in data analysis in order to evaluate human exposure to vibration according to the RMS procedure.

Another aspect of the evaluation of human exposure to vibrations in buildings is the measurement equipment used and the localisation of measurement points. According to ISO [7] vibration transmitted to the human body should be measured on the surface between body and that surface. This regulation is imprecise; however, in the notes of the ISO standard [6] it is written that vibrations transmitted to the body should be measured in the centre of rigid surfaces (usually within $10 \mathrm{~cm}$ of this area). The location of the measurement point is defined as the point of entry to the body in the standard [3]. For external excitation, such as transport-induced vibrations, one or two measurement points should be located in the central part of the floor within one-third and two-thirds of the width/length of the floor, according to [3]. Measurement equipment should consist of appropriate sensors, amplifiers and, in recent years, digital recording technology. Requirements mostly concern sensors, which should be sensitive for low-frequency signals, unlike the case for acoustic purposes. Requirements for measurement equipment are described in the newest version of [9].

The criteria used with regard to human exposure to vibration in buildings depends on the evaluation method. There are four main methods in which the following parameters are considered:

- acceleration (velocity) of vibration corrected across the whole frequency range,

- spectrum (frequency structure) of the effective value (RMS) of acceleration (velocity) of vibration in $1 / 3$ octave band, 
- vibration dose value $(V D V)$,

- maximum transient vibration value (MTVV).

ISO standard [6] defines the RMS method as a basic method of evaluation but notes that in some cases, additional methods should be used. As additional methods, ISO defines the $M T V V$ method and the $V D V$ method. These two methods, especially $V D V$, are recommended as additional methods in high crest factor situations. The $R M S$ method averages acceleration values in the duration time:

$$
a_{w}=\left[\frac{1}{T} \int_{0}^{T} a_{w}^{2}(t) d t\right]^{\frac{1}{2}}
$$

where: $a w(t)$ - is the weighted acceleration as a function of time $\left[\mathrm{m} / \mathrm{s}^{2}\right] ; T-$ is the duration of measurement [s].

$M T V V$ method also averages acceleration values but is more sensitive for occasional shocks and transient vibration by using a short integration time constant:

$$
\begin{gathered}
a_{w}\left(t_{0}\right)=\left[\frac{1}{\tau} \int_{t_{0}-\tau}^{t_{0}} a_{w}^{2}(t) d t\right]^{\frac{1}{2}} \\
M T V V=\max \left[a_{w}\left(t_{0}\right)\right]
\end{gathered}
$$

where: $\tau-$ is the integration time (for running averaging, is recommended to use $\tau=1 \mathrm{~s}$ ); $t_{0}$ - is the time of observation (instantaneous time).

The VDV method is the best for peaks in recorded signals because it uses the fourth power instead of the second power, as is used in RMS and MTVV:

$$
V D V=\left[\int_{0}^{T} a_{w}^{4}(t) d t\right]^{\frac{1}{4}}
$$

The corrected value is determined by measuring the vibration at the point at which it is transmitted to the person using the correction by means of a correction filter. This is a simple method which provides data relating to exceedance of comfort but does not include information regarding the frequency in which this exceedance appeared.

From the nineteen-eighties, not only have national and international standards changed, there has also been a lot of research conducted on human exposure to vibration. In [19] authors investigated the influence of the mode shape of motion on the human perception of vibration. During the experiment, horizontal vibrations in various shapes were induced. Vibrations were induced in clearly unidirectional directions ( $\mathrm{X}$ or $\mathrm{Y}$ ), and in circular and elliptical directions, all of different, very low frequencies. The participants of the experiment should identify the shapes of vibrations. The participants identified vibration evidently in one direction and vibration moving in a circular line. In the case of vibrations of elliptical motion, this identification was not so good. In [9] was also investigated the perception of harmonic 
vibration and vibration of a random character. It was revealed that in the frequency range of 0.3 to $0.6 \mathrm{~Hz}$, harmonic vibration is felt at a lower vibration amplitude than vibration of a random character. This means that the actual line of the vibration sensation threshold of harmonic vibrations in the considered frequency range lies lower than that of the corresponding line of random vibration.

The newest version of the Polish standard [17] was produced on the basis of an international literature review and in accordance with other international standards on that subject.

\section{New Polish regulations - evaluation methods}

In the newest version of the Polish standard [17], three evaluation methods are considered:

- RMS method of acceleration/velocity in $1 / 3$ octave bands,

- acceleration/velocity corrected in the whole frequency range,

- vibration dose value.

The RMS method is considered to be a basic evaluation method and $V D V$ is treated as an additional method and is described in Appendix A; this should be used as a probability of adverse comments.

The RMS method did not change from the old 1988 version [16] to the newest version $[17]$ and is very close to [7]. The only differences are related to the accuracy of the acceleration values in the middle frequencies in the $1 / 3$ octave bands which are used to determine the human perception threshold. The values of the corrected factor ' $n$ ' which are used to determine comfort levels during the daytime and night-time for different types of room (residential, office, workshops, hospitals etc.) and different types of vibrations (steady state and continuous) are the same as in [16] and in [6]. However, in [17], the new WODL ratio (in English, the human vibration perceptivity ratio) is proposed. It illustrates the percentage of exceedance of the perception threshold of vibration. This is the maximum ratio of the acceleration $R M S$ value obtained from the analysis to the acceleration $R M S$ value equivalent to the threshold for human perception of vibration (in the same $1 / 3$ octave band) chosen from each $1 / 3$ octave band. The advantage of such a coefficient is that the result of the analysis from the frequency band is not independent because the WODL clearly shows how many times the threshold for human vibration has been exceeded.

$$
W O D L=\max \left(\frac{a_{R M S}}{a_{z}}\right)
$$

where:

aRMS - acceleration RMS value obtained from analysis,

$a z \quad$ - acceleration $R M S$ value equivalent to the threshold for the perception of vibration in a $\mathrm{z}$-direction in the same $1 / 3$ octave band as in aRMS.

The VDV method is the new method in [17]. This method is clearly described in [3] in which the table of levels of probability of adverse comments is shown. The methodology for determining the $V D V$ value in [17] is the same like presented in standards [3] and [6]. It is 
worth noting that in [6], comfort levels are not given for this evaluation method. With regard to comfort levels, the Polish standard provides the standards shown in Table 1.

Table 1. Levels of probability of adverse comments from occupants

\begin{tabular}{|c|c|c|c|}
\hline Type of room & Time of day & $\begin{array}{c}\text { Low } \\
\text { probability } \\
\text { of adverse } \\
\text { comments }\end{array}$ & $\begin{array}{c}\text { Adverse } \\
\text { comments } \\
\text { possible }\end{array}$ \\
\hline$\left[\mathrm{m} / \mathbf{s}^{1.75}\right]$ & {$\left[\mathrm{m} / \mathbf{s}^{1.75}\right]$} \\
\hline $\begin{array}{c}\text { hospitals, } \\
\text { operating theatres, } \\
\text { precise laboratories }\end{array}$ & $\begin{array}{c}\text { day and } \\
\text { night }\end{array}$ & 0.10 & 0.20 \\
\hline residential & day & 0.20 & 0.40 \\
\cline { 2 - 4 } & night & 0.13 & 0.26 \\
\hline office & $\begin{array}{c}\text { day and } \\
\text { night }\end{array}$ & 0.40 & 0.80 \\
\hline workshops & $\begin{array}{c}\text { day and } \\
\text { night }\end{array}$ & 0.80 & 1.60 \\
\hline
\end{tabular}

The corrected value methodology and assessment is the same as in earlier version of [16] and it is mostly used for quick diagnosis because there is no information about the frequency in which the comfort level is exceeded.

\section{New Polish regulations - measurements}

With regard to measurements concerning accelerations and velocities of vibrations, according to the new version of the Polish standard, measurements should be performed in the room in which occupants perceive vibrations. Measurement sensors should be placed at the points at which vibrations are transmitted to the body. Measurements should be performed in conditions in which the vibrations that are perceived by occupants have the most harmful influence. The measurement should be taken at a specific measuring point on the floor. Unless there are overriding reasons, by default, the location of the measurement point should be the geometric centre of the room. Exceptions could be when the floor is of an irregular structure or when the floor has additional structural elements which stiffen the floor structure; this is why the assistance of building engineer is required.

The basic measurement method is the recording of vibrations in the time domain at selected measuring points in the frequency range from 1 to $120 \mathrm{~Hz}$. A frequency of $120 \mathrm{~Hz}$ is required for low-pass filtering. A filter with damping characteristics should be chosen to allow frequencies below $80 \mathrm{~Hz}$ to pass for evaluation.

It is recommended to use a measurement disc for measuring vibrations that are perceptible to humans; this should be placed at the measurement point. Sensors for measuring vibration parameters in three perpendicular directions should be securely fastened to the disc. Such a disc 


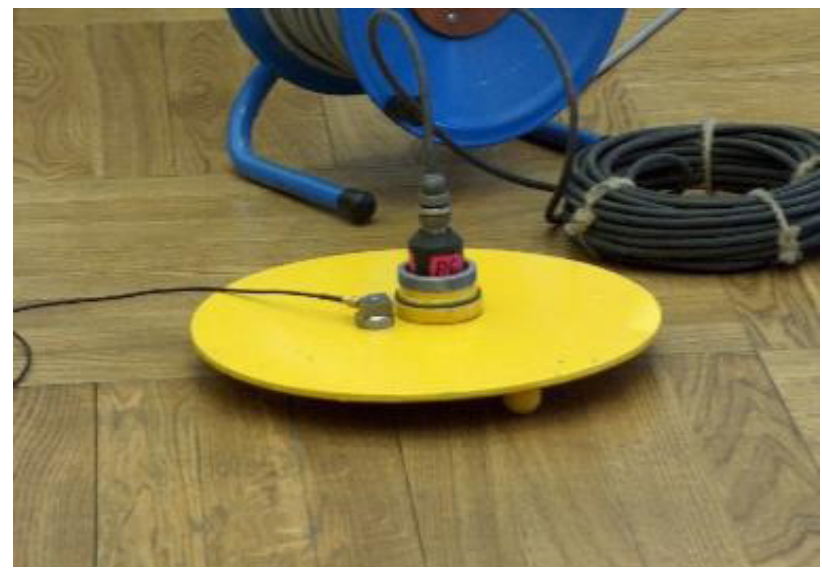

Fig. 2. Old version of measuring disc

should be supported at three points and should have diameter of $30 \mathrm{~cm}$ and a mass of at least $30 \mathrm{~kg}$. Additional mass should be used to reach the minimum recommended weight. Similar discs were used by the Laboratory of Structural Distortion and Vibration of the Institute of Structural Mechanics before the new version of [17] was published; this is shown in Fig. 2 .

Due to the number of measuring channels and the known direction of vibrations, vertical vibrations of the floor were most often measured (Fig. 1). After analysing the results of vibration measurements, it turned out that in some cases, the mass of the disk itself - a few kilograms, was insufficient and some problems appeared. Based on experience, the disk was loading using $10 \mathrm{~kg}$ weights. Initially, two weights were used, and ultimately there were three on each of the measuring discs (Fig. 3).

The advantage of the measurement disk over other methods was the ability to measure vibrations in a non-invasive and non-destructive manner, which is very important in residential houses.

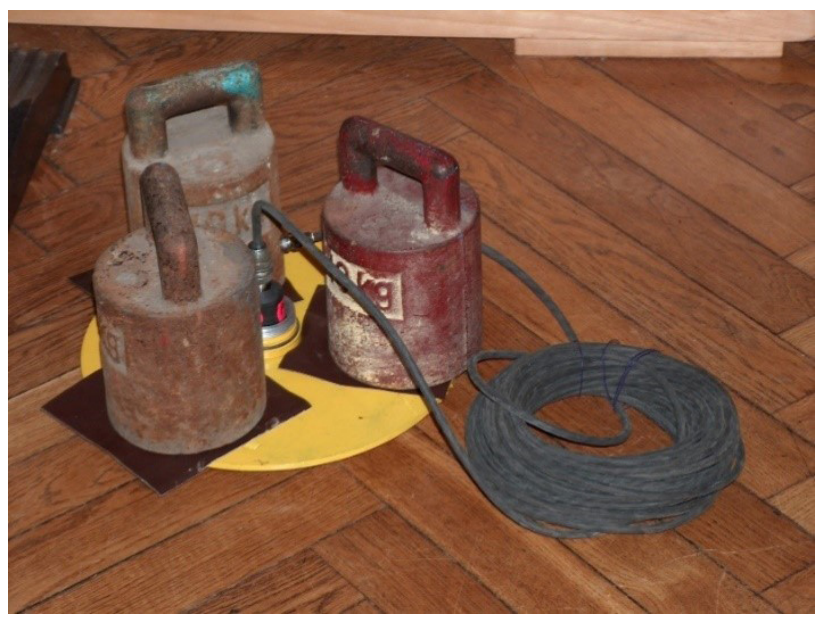

Fig. 3. Old version of measuring disc with three additional weights 
The optimal location for weights was debatable and some problems with vibrations of additional weights occurred. This is why the need for steady mass distributions appeared. In the literature, a solution is proposed in [14]. This is a steel disk with a diameter of $300 \mathrm{~mm}$ and a thickness of $4 \mathrm{~mm}$, with three support points (legs) positioned at angles of $120^{\circ}$ to each other (Fig. 4). In accordance with the USSR solution, in [18] a new disc was proposed (Fig. 5).

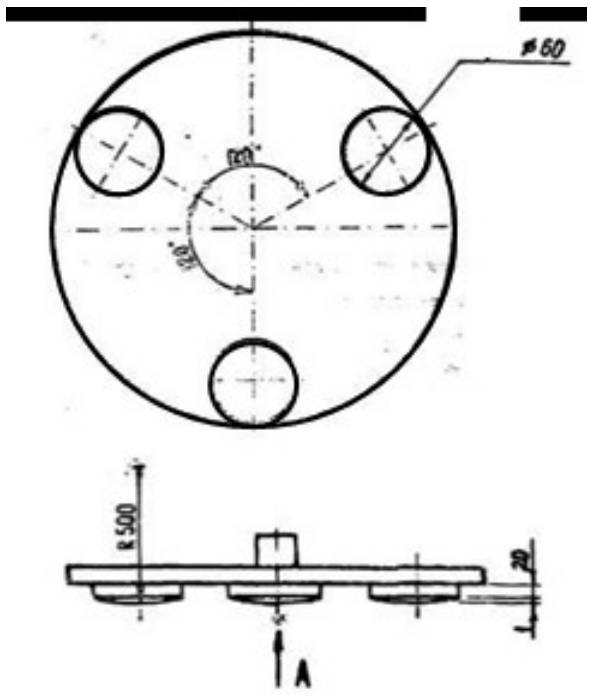

\section{Bua A}

Fig. 4. Plan and cross section of the disc used in USSR

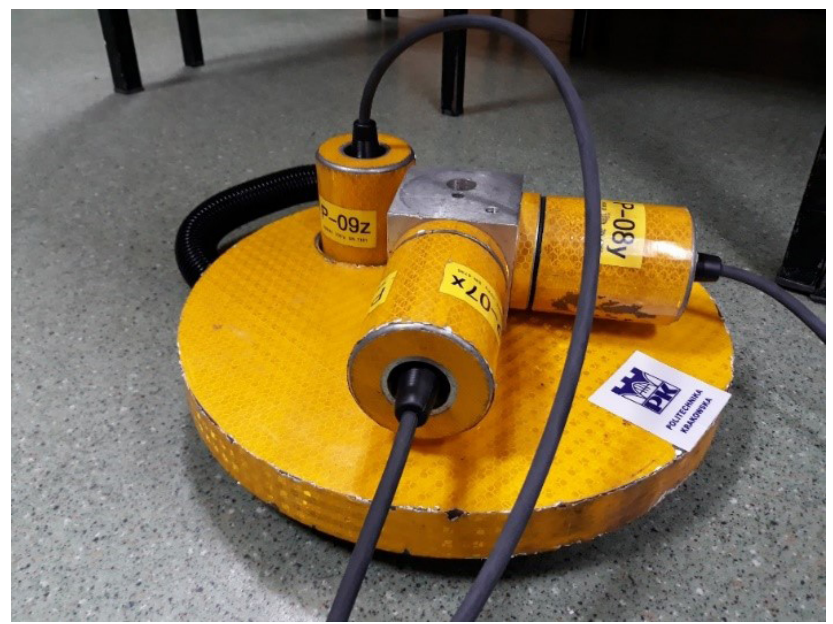

Fig. 5. New disc proposal 
The proposed solution is free from the disadvantages of other previously used devices. The disk is an integral system with a sensor mounting and a load ensuring good contact of the disk with the floor surface regardless of its structure and surface layer. The disc enables noninvasive measurements and repeatability of results.

\section{New Polish regulations - duration of vibration}

In [6], duration of vibration is not clearly described. According to the ISO, the duration of measurement of human exposure to vibration should be sufficient to ensure statistical precision and to ensure that the vibration is typical of the exposures which are being assessed. In general, a minimum of 30 minutes should be recorded and analysed according to the ISO procedure.

In the Polish standard (both the older [16] and newer versions [17]), the duration of vibration is the range in which the vibration amplitudes are higher than 0.2 of maximum amplitude; this range should be taken for the RMS procedure. Moreover, one dynamic event of comfort exceedance can influence on the results of evaluation of human exposure to vibration. Polish regulations are stricter than those included in the ISO [6] or other national standards. The procedure which is in the Polish regulations is more like the MTVV procedure than the RMS procedure. The duration of vibration, in accordance with the Polish regulations, is shown in Fig. 6.

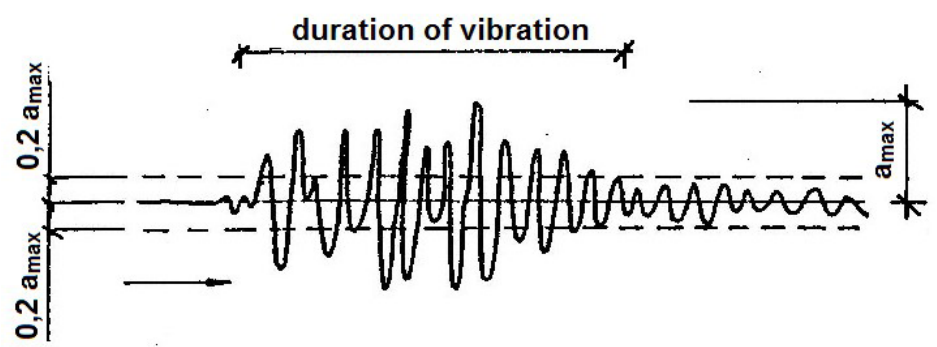

Fig. 6. Duration of vibration in accordance with [16] and [17]

The classical RMS method, with 30 minutes of averaging, turned out to be inadequate for transport situations. People residing close to a road, railway or tramway infrastructure complained, although the classical RMS procedure indicates that there is no problem with comfort exceedance. The reason for this kind of situation could be a high value of the so-called crest factor for some transport vibrations. The crest factor is defined as the modulus of the ratio of the maximum instantaneous peak value of the frequency weighted acceleration signal to its $R M S$ value:

$$
C F=\frac{\left|a_{w}\right|_{\text {PEAK }}}{a_{w R M S}}
$$

For vibration with a crest factor below or equal to 9, the RMS method, which is called the basic method, is sufficient. However, for some types of vibration with occasional shocks, the basic evaluation method could underestimate values of discomfort. This is why an additional 
method should be used in cases of higher crest factor values. In [6], it is written that the basic RMS method should always be used for the evaluation of human comfort with regard to vibration. However, in cases where an additional method is also used (ex. $C F>9$ ), both results from the basic evaluation method and from the additional evaluation method should be reported.

In the older version of Polish standard [16], it was written that regulations included in the standard can be used for crest factor values below 9. This was because in the older version, there was no additional method. In the Australian standard [2], the ranges of the crest factor are different:

- when the crest factor is lower than $6(C F<6)-R M S$ should be used,

- when crest factor is in the range of 6 to $9(C F \geq 6$ and $C F \leq 9)-R M S$ and $V D V$ should be used together,

- when the crest factor is higher than $9(C F>9)-V D V$ should be used.

\section{Examples}

To investigate accurate of the new Polish regulations, in-situ measurements were performed on a five-storey reinforced office building located in Cracow. The building is subjected to transport excitation coming from the road, the edge of which edge is $2 \mathrm{~m}$ from the outer wall of the analysed building. Twelve dynamic events were chosen in which, according to the RMS method, the comfort level is exceeded. Example of $R M S$ evaluation is shown in Fig. 7.

As can be seen from Fig. 7, for the frequency band equal to $10 \mathrm{~Hz}$, the comfort level is exceeded during both night and day. The crest factor in this case is 6.35. The VDV value for this measurement (no. 151) is 0.58 which means that according to Table 1, complaints from residents are possible. In this case, both methods yield the same result.

In Table 2, the results of the evaluation of human exposure to vibration for the twelve chosen dynamic events are listed.

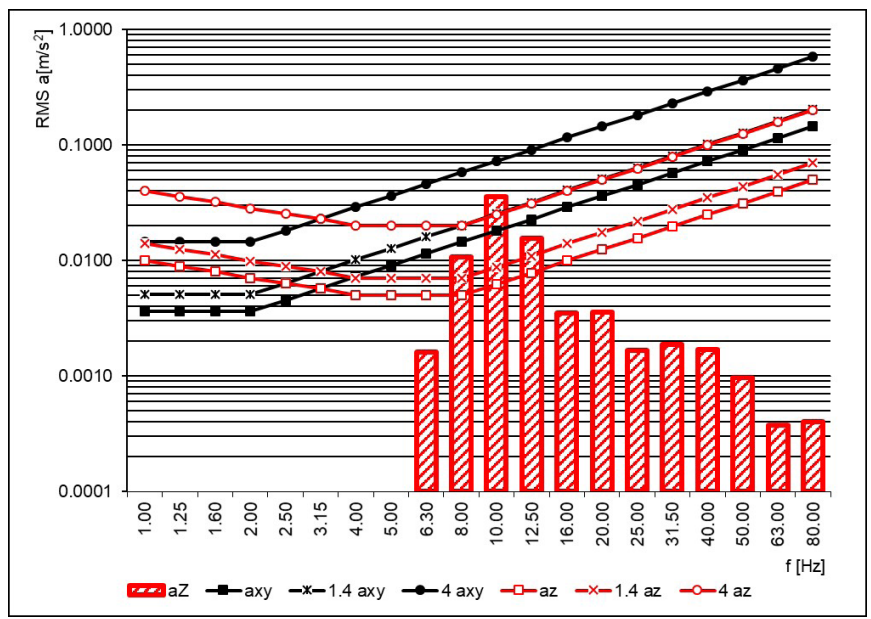

Fig. 7. RMS evaluation for measurement no. 151 
Table 2. Results of RMS and VDV methods

\begin{tabular}{|c|c|c|c|c|}
\hline Measurement no. & Time of day & Crest factor & WODL value & VDV value \\
\hline & & {$[-]$} & {$[-]$} & {$\left[\mathrm{m} / \mathbf{s}^{\mathbf{1} 75}\right]$} \\
\hline 151 & day & 6.35 & 5.76 & 0.58 \\
\hline 292 & day & 6.70 & 3.92 & 0.45 \\
\hline 320 & day & 6.82 & 11.81 & 0.94 \\
\hline 555 & day & 9.11 & 10.80 & 0.97 \\
\hline 601 & day & 10.65 & 4.91 & 0.58 \\
\hline 1344 & night & 5.33 & 4.03 & 0.50 \\
\hline 1348 & night & 5.45 & 2.26 & 0.38 \\
\hline $1385 \mathrm{a}$ & night & 5.09 & 1.61 & 0.32 \\
\hline $1385 \mathrm{~b}$ & night & 5.94 & 1.06 & 0.32 \\
\hline $1397 \mathrm{a}$ & night & 5.01 & 4.32 & 0.46 \\
\hline $1397 \mathrm{~b}$ & night & 5.39 & 5.19 & 0.57 \\
\hline 1407 & day & 7.33 & 2.39 & 0.46 \\
\hline
\end{tabular}

In Table 2, the orange rows are dynamic events in which crest factor is higher than 9, and the yellow rows refer to cases in which the crest factor is in the range of 6 to 9.

In the dynamic events in which the crest factor is higher than 9, the evaluation of human exposure to vibration indicates that for measurement no. 555, both methods indicate exceedance of the comfort level, but for measurement no. 601, the RMS max is higher than 4.0 which means that the comfort level is exceeded, and $V D V$ is in the mid-range between low probability and possibility of complaints.

In cases in which the crest factor is in the range of 6 to 9 , in three out of four cases, the evaluations made in accordance with both methods is equal. There is one exception for measurement no. 151, in which the RMS max indicates that comfort level is exceeded while the $V D V$ is in the mid-range.

For crest factors below 6, for all dynamic events, results of the evaluations made with the two methods differ. The $V D V$ method underestimates the human perception of vibration within this range.

It is worth noting that the RMS procedure included in [17] is close to the MTVV method included in [6]. The comparison included in this paper refers to methods included in the Polish standard, and can be treated as a comparison between two additional methods from the ISO standard.

\section{Conclusion}

In this paper, new regulations of Polish standard [17] are clearly described. There are significant changes in this standard in comparison with the previous version. The new method of evaluation of human exposure to vibration is included in an attachment. This method, 
called the $V D V$ (vibration dose value), is known from such standards as: international [6], British BS [3] and Australian [2]. It is described in literature as being more sensitive to peaks in the recorded signal than the classical RMS method, which was introduced in [6] as the basic evaluation method.

The RMS method with a duration time in the region of 0.2 max amplitudes is still the basic method of evaluation in the new version of [17]. In order to improve the readability of results and to improve the quality of the assessment, the WODL ratio was proposed as an illustration of evaluation results. This ratio is very useful because it shows whether and to what extend the threshold of perception has been exceeded.

Special disc requirements were included in [17] to improve and unify measurement equipment. This is very important because according to the experience of the authors of the new Polish regulations, there were many mistakes regarding the usage of inappropriate measurement equipment. In particular, the location of measurement points and the fixing of sensors was inappropriate.

In this paper, two evaluation methods of human exposure to vibration included in the Polish standard [17] have been investigated and compared. Results show that the RMS max method, very close to the MTVV method, gives equal or higher values of evaluation than the $V D V$ method. This means that results from such evaluations are on the safe side and people residing in houses designed according to these requirements are protected from the negative influence of vibrations.

The VDV method requires improvement; in particular, the levels of probability of adverse comments need to be changed. Additional measurements on humans in buildings in the zones of dynamic influences should be performed in order to improve this method.

\section{References}

[1] Architectural Institute of Japan, Guidelines for the evaluation of habitability to building vibration, AIJ-GEH-2004.

[2] AS 2670.2. Evaluation of human exposure to whole-body vibration Continuous and shock-induced vibration in buildings (1 to $80 \mathrm{~Hz}), 1990$.

[3] British Standards Institution, BS 6472-1. Guide to evaluation of human exposure to vibration in buildings. Vibration sources other than blasting, 2008.

[4] British Standards Institution, BS 6841. Measurement and evaluation of human exposure to whole-body mechanical vibration and repeated shock, 1987.

[5] DIN 4150-2. Structural vibration, Part 2: Human exposure to vibration in buildings, 1999.

[6] International Organization for Standardization, ISO 2631-1. Mechanical vibration and shock: Evaluation of human exposure to whole-body vibration - Part 1: General requirements, 1997. 
[7] International Organization for Standardization, ISO 2631-2. (2003) Mechanical vibration and shock - Evaluation of human exposure to whole-body vibration - Part 2: Vibration in buildings $(1 \mathrm{~Hz}$ to $80 \mathrm{~Hz}$ ).

[8] International Organization for Standardization, ISO 6897, Guidelines for the evaluation of the response of occupants of fixed structures, especially buildings and off-shore structures, to low frequency horizontal motion $(0,063$ to $1 \mathrm{~Hz}), 1984$.

[9] International Organization for Standardization, ISO 8041-1. Human response to vibration-measuring instrumentation. Part 1: general purpose vibration meters, 2017.

[10] Kim Y.C., Tamura Y., Tanaka H., Ohtake K., Bandi E.K., Yoshida A., Wind-induced responses of super-tall buildings with various atypical building shapes, J. Wind Eng. Ind. Aerodyn. 133, 2014, 191-199.

[11] Kouroussis G., Verlinden O., Conti C., Contribution of vehicle/track dynamics to the ground vibrations induced by the Brussels tramway, Proceedings of ISMA 2including USD, 2010.

[12] Lee P.J., Lee B.K., Griffin M.J, Evaluation of floor vibrations induced by walking in reinforced concrete buildings, Proc. of Inter Noise Conference, Innsbruck/Austria, 15-18 September 2013, 1-6.

[13] Lombaert G., Degrande G., François S., Thompson D.J., Ground-Borne Vibration due to Railway Traffic: A Review of Excitation Mechanisms, Prediction Methods and Mitigation Measures, [in:] J. Nielsen et al. (eds.), Noise and Vibration Mitigation for Rail Transportation Systems, Notes on Numerical Fluid Mechanics and Multidisciplinary Design, vol. 126. Springer, Berlin, Heidelberg 2015.

[14] Ministry of Health of the USSR No. 2957-84, Methodological recommendations regarding the measurement and hygienic assessment of vibrations in residential buildings, 1984.

[15] Papán D., Valašková V., Road and Railway Traffic Seismicity Effect Comparison on Historical Building in Slovakia, IOP Conf. Ser.: Earth Environ. Sci. 44 042017, 2016.

[16] PN-B-02171:1988, Ocena wpływu drgań na ludzi w budynkach, Polish Standard 1988.

[17] PN-B-02171:2017-06, Ocena wplywu drgań na ludzi w budynkach, Polish Standard 2017.

[18] Stypuła K., Stecz P., Chełmecki J., Zgłoszenie patentowe nr W.125639, 29 września 2016.

[19] Tamura Y., Kawana S., Nakamura O., Kanda J., Nakatà S., Evaluation perception of windinduced vibration in buildings, Structures \& Buildings, 159, 2006, 1-11.

[20] Tatara T., Pachla F., Kuboń P., Experimental and numerical analysis of an industrial RC tower, Bulletin of Earthquake Engineering, Vol. 15, Iss. 5, 2017, 2149-2171. 